\title{
Pengaruh Model Pembelajaran Talking Stick Berbantuan Rubrik Surat Kabar Terhadap Keterampilan Berbicara
}

\author{
I Nym. Putra Antara ${ }^{1 *}$, M. G. Rini Kristiantari² I Ngh. Suadnyana ${ }^{3}$
}

${ }^{123} J$ urusan Pendidikan Dasar, Universitas Pendidikan Ganesha, Singaraja, Indonesia

\author{
A R T I CLE I NFO \\ Article history: \\ Received 18 August 2019 \\ Received in revised form \\ 19 September 2019 \\ Accepted 25 October 2019 \\ Available online 30 \\ November 2019 \\ Kata Kunci: \\ keterampilan berbicara, \\ talking stick, surat kabar \\ Keywords: \\ speaking skill, talking stick, \\ newspaper
}

\begin{abstract}
A B S T R A K
Penelitian ini bertujuan untuk mengetahui pengaruh model pembelajaran talking stick terhadap keterampilan berbicara pada siswa kelas V SD Negeri Gugus IX Kintamani Tahun Ajaran 2017/2018. Jenis penelitian ini adalah penelitian eksperimen semu dengan rancangan nonequivalent control group design. Populasi penelitian ini adalah seluruh siswa kelas V SD Negeri di Gugus IX Kintamani sebanyak 315 orang yang tersebar menjadi 11 kelas. Sampel ditentukan dengan menggunakan teknik random sampling. Sampel dalam penelitian ini adalah siswa kelas V SD N 6 Songan sebanyak 37 orang sebagai kelompok eksperimen dan siswa kelas V SD N 9 Songan sebanyak 38 orang sebagai kelompok kontrol. Pengumpulan data dilakukan dengan rubrik penilaian keterampilan berbicara. Data yang diperoleh dianalisis menggunakan uji-t (polled varians). Hasil penelitian menunjukkan bahwa thitung $=2,463$ sedangkan pada taraf signifikansi $5 \%$ dengan $\mathrm{dk}$ $=73$ diperoleh nilai ttabel $=2,000$ sehingga thitung $=2,463>$ ttabel=2,000. Berdasarkan kriteria pengujian, maka $\mathrm{HO}$ yang berbunyi tidak terdapat pengaruh model pembelajaran talking stick berbantuan rubrik surat kabar terhadap keterampilan berbicara siswa kelas V SD
\end{abstract} Negeri gugus IX Kintamani tahun ajaran 2017/2018 ditolak dan Ha diterima. Dengan demikian dapat disimpulkan bahwa model pembelajaran talking stick berbantuan rubrik surat kabar berpengaruh terhadap keterampilan berbicara siswa kelas V SD Negeri gugus IX Kintamani tahun ajaran $2017 / 2018$.

\section{A B S T R A C T}

This research model of the Talking Stick model of Speaking for 5th grade students of SD Gugus IX Kintamani in the academic year 2017/2018. This research type was quasi experimental research with nonequivalent control group design. The population of this research was all students of of $5^{\text {th }}$ grade students in SD Gugus IX Kintamani in the academic year 2017/2018 amounted to 315 students which scattered into 11 classes. The samples were determined by using random sampling technique. The sample of this research were the students of $5^{\text {th }}$ A grade in SD Negeri 6 Songan amounted 37 students as the experimental group and the students of $5^{\text {th }} A$ grade in SD Negeri 9 Songan amounted 38 students as the control group. The data were collected by using the assesment rubric for speaking. The data was analyzed by using $t$-test. Result of the research shows that $t_{\text {count }}=2,463$ meanwhile at $5 \%$ significance level with $d f=73$ obtained $t_{\text {table }}=2,000$, so $t_{\text {count }}=2,463>t_{\text {table }}=2,000$. Based on the testing criteria, $H_{0}$ which sounded there is no significant differences of speaking skill between the group of students who were taught by talking stick model and the group of students who were taught by conventional learning of $5^{\text {th }}$ grade students of SD Gugus IX Kintamani in the academic year 2017/2018 was refused and $H_{a}$ was recieved. So it can be concluded that there is an effect of Talking Stick model on the speaking skill of $5^{\text {th }}$ grade students of SD Gugus IX Kintamani in the academic year 2017/2018.

Copyright (C) Universitas Pendidikan Ganesha. All rights reserved.

\footnotetext{
${ }^{1}$ Corresponding author.

E-mail addresses: Citraanggara01@Gmail.com (I Nym. Putra Antara)
} 


\section{Pendahuluan}

Pendidikan merupakan hal yang sangat penting, karena pendidikan memiliki peran penting dalam upaya peningkatan sumber daya manusia ke arah yang lebih baik. Diharapkan melalui pendidikan mampu membentuk siswa agar dapat mengembangkan sikap, keterampilan dan kecerdasan intelektualnya sehingga menjadi manusia yang terampil, cerdas, serta berakhlak mulia.

Pendidikan di sekolah dikenal dengan istilah pendidikan formal karena semua aspek dalam pendidikan di sekolah ditata secara formal (Wardani,2014). Walau demikian, sistem yang diterapkan selalu mengalami perubahan. Salah satu perubahan yang masih sering diperbincangkan adalah kurikulum. Seiring dengan perkembangan jaman, kurikulum di Indonesia terus mengalami perubahan. Kurikulum 2013 yang sudah mulai diaplikasikan pada pertengahan tahun ajaran 2013/2014 adalah bentuk penyempurnaan terbaru. Meski demikian masih banyak sekolah yang saat ini menggunakan Kurikulum Tingkat Satuan Pendidikan (KTSP).

Pendidikan merupakan suatu proses yang diperlukan untuk mendapatkan keseimbangan dan kesempurnaan dalam perkembangan individu maupun masyarakat. Penekanan pendidikan dibanding dengan pengajaran terletak pada pembentukan kesadaran dan kepribadian individu atau masyarakat di samping transfer ilmu dan keahlian. Dengan proses semacam ini suatu bangsa atau negara dapat mewariskan nilai-nilai keagamaan, kebudayaan, pemikiran dan keahlian kepada generasi berikutnya, sehingga mereka betul-betul siap menyongsong masa depan kehidupan bangsa dan negara yang lebih cerah. Pendidikan juga merupakan sebuah aktifitas yang memiliki maksud atau tujuan tertentu yang diarahkan untuk mengembangkan potensi yang dimiliki manusia baik sebagai manusia ataupun sebagai masyarakat dengan sepenuhnya (Nurkholis, 2013).

Kurikulum pada hakekatnya merupakan salah satu alat yang sangat strategis dan menentukan dalam pencapaian tujuan-tujuan pendidikan. Kedudukan dan posisi kurikulum pada tingkat satuan pendidikan ini merupakan bagian yang vital, bahkan menjadi syarat mutlak dan bagian yang tak terpisahkan dari keseluruhan proses pendidikan sehingga sangat sulit dibayangkan bagaimana bentuk pelaksanaan pendidikan yang tidak memiliki kurikulum. Dengan demikian, pada dasarnya bukan hanya guru yang harus memahami tentang hakikat kurikulum ini, tetapi semua pihak yang terlibat dalam pelaksanaan pendidikan di sekolah idealnya dapat memahami hakikat kurikulum sesuai dengan bidang tugas masing-masing.

Lebih lanjut Wardani (2014) berpendapat bahwa kurikulum merupakan salah satu aspek dalam program pendidikan dan merupakan jantung serta pusat pendidikan sehingga tanpa kurikulum, pendidikan tidak akan berlangsung. Pengembangan KTSP merupakan salah satu upaya untuk mengatasi masalah pendidikan khususnya relevansi pendidikan. Dengan pemberlakuan otonomi pengelolaan pendidikan dan manajemen berbasis sekolah, setiap sekolah dituntut untuk dapat mengembangkan siswa serta tuntutan dan potensi daerah yang ada. Selain itu profesionalisme guru juga merupakan alasan lain perlunya pengembangan KTSP. Seorang guru profesional dituntut untuk mampu mengembangkan, melaksanakan dan mengevaluasi kurikulum. Kompetensi pengembangan kurikulum merupakan bagian integral dan profesionalisme guru.

Anitah (2014) menyatakan guru harus berupaya menerapkan kurikulum yang telah ditetapkan secara maksimal dan efektif sehingga mencapai target kurikulum yang telah ditetapkan. Implementasi KTSP dalam pembelajaran yang efektif dan menyenangkan menuntut guru untuk lebih sabar, penuh perhatian dan pengertian, serta mempunyai kreativitas dan penuh dedikasi untuk menumbuhkan rasa percaya diri siswa. Kondisi demikian akan menumbuhkan suasana yang kondusif dalam pembelajaran, yang akan menimbulkan rasa persahabatan antara guru dengan siswa sehingga mereka tidak canggung mengungkapkan dan mau membicarakan berbagai permasalahan yang dihadapi. Melalui berbicara siswa mampu menyampaikan permasalahan dan gagasan yang dimilikinya kepada orang lain. Hal itu tercapai apabila guru mampu berkomunikasi dengan seimbang dan multi arah, khususnya dalam kegiatan pembelajaran di kelas. Atas alasan itulah guru wajib menguasai dan memiliki keterampilan berbicara.

Keterampilan berbicara masih dianggap sebagai suatu pembelajaran yang mudah, mengingat secara alamiah seseorang mampu berbicara. Padahal pada kenyataannya, masih banyak siswa yang kurang mampu menyampaikan ide dan gagasannya melalui komunikasi secara lisan dalam situasi formal. Dalam proses belajar mengajar khususnya kegiatan berbicara, siswa sering kali malu dan merasa gugup ketika diminta berbicara atau bercerita di depan kelas.

Bicara merupakan salah satu alat komunikasi yang paling efektif. Semenjak anak masih bayi sering kali menyadari bahwa dengan mempergunakan bahasa tubuh dapat terpenuhi kebutuhannya. Berbicara sebagai suatu cara berkomunikasi, manusia sebagai makhluk sosial dan tindakan utama dan paling penting adalah tindakan sosial, suatu tindakan tepat saling menukar pengalaman, saling mengemukakan dan menerima pikiran, saling mengutarakan perasaan atau saling mengekspresikan. Keterampilan 
berbicara siswa harus dilatih melalui proses belajar dan latihan secara berkesinambungan dan sistematis agar dapat memperlancar siswa dalam berkomunikasi. Bagi anak, bicara tidak sekedar merupakan prestasi akan tetapi juga berfungsi untuk mencapai tujuannya misalnya, sebagai pemuas kebutuhan dan keinginan, sebaga alat untuk menarik perhatian orang lain, sebagai alat untuk membina hubungan sosial, sebagai alat untuk mengevaluasi diri, untuk dapat memperngaruhi pikiran dan perasaan orang lain, serta untuk mempengaruhi perilaku orang lain. Guru sebagai seorang pendidik harus dapat menjadi model pembelajaran yang baik bagi peningkatan keterampilan berbicara siswa.

Berdasarkan pengalaman pada saat melaksanakan observasi dan wawancara dengan beberapa kepala sekolah di desa Songan, sebagian besar siswa mengalami kesulitan dalam keterampilan berbicara saat diminta untuk berbicara di depan kelas. Keterampilan berbicara secara praktik masih kurang dikuasai siswa. Hal ini disebabkan praktik berbicara yang dilakukan siswa dalam pembelajaran masih kurang maksimal.

Penyebab kesulitan berbicara tersebut tidak terlepas dari penggunaan metode pembelajaran yang digunakan oleh guru. Kenyataan yang terjadi di lapangan, guru kurang memanfaatkan metode-metode pembelajaran yang inovatif dalam proses pembelajaran. Metode pembelajaran yang kurang inovatif membuat pembelajaran di kelas menjadi membosankan. Hal tersebut menyebabkan rendahnya sikap berpikir kritis, kreatif, dan sikap kerja keras siswa dalam belajar, padahal dengan adanya metode pembelajaran yang inovatif dan menyenangkan dapat membantu siswa lebih aktif dan kreatif dalam proses pembelajaran.

Guru sebagai fasilitator yang akan mengembangkan keterampilan berbicara dengan metode dan media yang efektif untuk membelajarkan keterampilan berbahasa agar pembelajaran berlangsung sesuai rencana.Guru harus dapat melihat situasi kelas atau siswa dan kemudian memilih media seperti apa yang akan di gunakan dalam pembelajarannya. Namun, dalam pemilihan media pembelajaran tetap mengacu pada tujuan utama dalam pencapaian belajar yaitu penekanan pada unsur pemahaman siswa, bukan sekedar menghafal.

Untuk menghadirkan suasana belajar yang menyenangkan bagi siswa maka seorang guru harus mengetahui cara-cara atau modelyang harus diterapkan, sehingga siswa termotivasi untuk mengikuti kegiatan pembelajaran. Oleh karena itu siswa perlu adanya model pembelajaran yang berbasis permainan disamping terpenuhinya kebutuhan akan permainan dan hiburan, kebutuhan akan pengetahuan juga akan terpenuhi lewat pembelajaran yang menggunakan metode permainan, salah satunyaadalah model pembelajaran Talking Stick.

Talking Stick (tongkat berbicara) adalah metode yang pada mulanya digunakan oleh penduduk asli Amerika untuk mengajak semua orang berbicara atau menyampaikan pendapat dalam suatu forum. Tongkat berbicara telah digunakan selama berabad-abad oleh suku-suku Indian sebagai alat menyimak secara adil dan tidak memihak. Tongkat berbicara sering digunakan kalangan dewan untuk memutuskan siapa yang mempunyai hak berbicara. Pada saat pimpinan rapat mulai berdiskusi dan membahas masalah, ia harus memegang tongkat berbicara. Tongkat akan pindah ke orang lain apabila ia ingin berbicara atau menanggapinya. Dengan cara ini tongkat berbicara akan berpindah dari satu orang ke orang lain jika orang tersebut ingin mengemukakan pendapatnya.

Model pembelajaran Talking Stick merupakan salah satu model pembelajaran yang mendorong siswa untuk berbicara dan mengeluarkan pendapat. Model pembelajaran ini dilakukan dengan bantuan tongkat. Tongkat dijadikan sebagai jatah atau giliran untuk berpendapat atau menjawab pertanyaan dari guru setelah siswa mempelajari materi pelajaran. Model ini sangat sederhana dipraktekkan dan cukup mudah untuk dipraktekkan khususnya pada siswa-siswa SD.

Pembelajaran talking stick diawali oleh penjelasan guru mengenai materi pokok yang akan dipelajari. Siswa diberi kesempatan membaca dan mempelajari materi tersebut. Guru selanjutnya meminta kepada siswa menutup bukunya. Guru mengambil tongkat yang telah dipersiapkan sebelumnya. Tongkat tersebut diberikan kepada salah satu siswa, kemudian tongkat bergulir dari satu siswa ke siswa yang lain dengan diiringi musik. Ketika musik berhenti, siswa yang mendapatkan tongkat wajib menjawab pertanyaan. Tongkat akan bergulir lagi dari siswa yang terakhir menjawab pertanyaan, demikian seterusnya hingga seluruh pertanyaan telah dijawab .

Langkah akhir dari metode talking stick adalah guru memberikan kesempatan kepada siswa melakukan refleksi terhadap materi yang telah dipelajarinya. Guru memberi ulasan terhadap seluruh jawaban yang diberikan siswa, selanjutnya bersama-sama siswa merumuskan simpulan.

Talking Stick merupakan jenis pembelajaran yang dirancang untuk menguji kesiapan peserta didik dalam menjawab pertanyaan dan materi yang telah mereka pelajari sebelumnya. Dengan menerapkan model kooperatif tipe Talking Stick diharapkan dapat meningkatkan hasil belajar peserta didik. Selain sebagai metode agar siswa mau berpendapat, tapi juga untuk melatih siswa untuk berani berbicara. Dengan model pembelajaran ini suasana kelas bisa terlihat lebih hidup dan tidak monoton. 
Kelebihan model pembelajaran ini adalah menguji kesiapan siswa dalam penguasaan pembelajaran, melatih membaca ataupun memahami dengan lebih cepat materi yang telah dipelajari, dan melatih keterampilan berbicara siswa pada saat pembelajaran berlangsung. Model pembelajaran talking stick dapat meningkatkan cara belajar siswa menuju belajar lebih baik, mendorong siswa untuk berani mengemukakan pendapat. Selain itu, model pembelajaran talking stick juga bertujuan untuk meningkatkan partisipasi siswa, memberikan kesempatan pada siswa untuk berinteraksi dan belajar bersama-sama. Kelebihan dari penggunaan metode pembelajaran Talking Stick menguji kesiapan siswa dalam menerima pembelajaran, membuat siswa membaca dan memahami pelajaran dengan cepat dan membuat siswa belajar lebih giat, sehingga diharapkan dapat meningkatkan prestasi siswa

Dalam pelaksanaan pembelajaran, guru memberikan variasi dalam pembelajaran dengan menggunakan media. Memilih media harus selalu dikaitkan dengan kompetensi/tujuan pembelajaran yang akan dicapai, sifat-sifat bahan ajar yang akan disampaikan, strategi pembelajaran yang akan digunakan. Media pembelajaran banyak ragamnya dan yang paling penting adalah media pembelajaran yang jarang diterapkan pada suatu kelas, salah satunya adalah rubrik surat kabar.

Surat kabar merupakan media massa cetak paling tua dibandingkan media massa cetak lainnya, seperti buku, majalah, dan tabloid. Bahkan, sampai hari ini surat kabar merupakan media massa cetak yang paling banyak dinikmati oleh para pembaca (reader) di seluruh dunia. Berdasarkan daya edarnya, jenis-jenis surat kabar dapat kita golongkan atas surat kabar internasional, nasional, dan lokal. Surat kabar internasional yaitu surat kabar yang daya edarnya bersifat internasional. Seperti surat kabar Sunday Time, The Jakarta Post, The Strait Times, dan lain sebagainya.

Surat kabar memberikan informasi mengenai hal tertentu, rubrik pada surat kabar pun membuat pembaca lebih mudah mencari informasi yang diinginkan. Surat kabar di lingkungan sekolah merupakan hal yang sudah tidak asing lagi, tetapi surat kabar dapat mengalihkan perhatian siswa jika diterapkan menjadi media pembelajaran.

Berdasarkan uraian tersebut, model pembelajaran talking stick dan media rubrik surat kabar mampu memberikan pengaruh terhadap keterampilan berbicara siswa. Untuk mengetahui pengaruh model dan media tersebut terhadap keterampilan berbicara siswa, maka dilakukan penelitian yang berjudul "Pengaruh Model Pembelajaran Talking Stick Berbantuan Rubrik Surat Kabar terhadap Keterampilan Berbicara Siswa Kelas V SD Negeri Gugus IX Kintamani Tahun Ajaran 2017/2018”

\section{Metode}

Penelitian ini dilaksanakan di SD Negeri Gugus IX Kintamani. Penelitian ini dirancang pada kelas V semester genap tahun ajaran 2017/2018. Rancangan penelitian yang digunakan dalam penelitian ini adalah penelitian kuantitatif dengan desain eksperimen semu (quasi eksperimental design) dalam bentuk nonequivalent control group design.

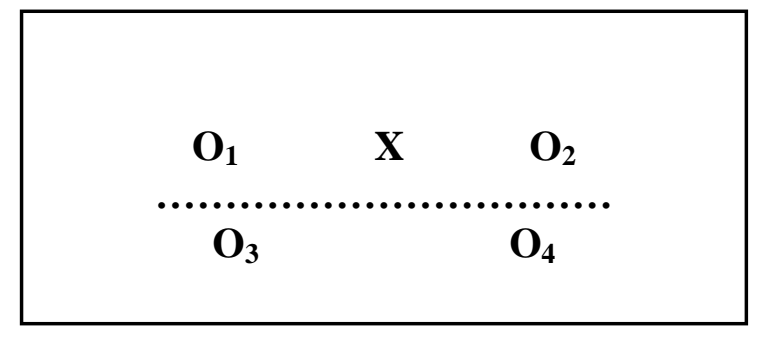

Gambar 1. Rancangan Penelitian

Dalam desain ini terdapat dua kelompok, yaitu kelompok eksperimen dan kelompok kontrol. Dalam penelitian ini pre-test dilakukan dengan menganalisis nilai Ulangan Tengah Semester (UTS) pada kelompok eksperimen dan kelompok kontrol sebagai penyetaraan kelompok. Selanjutnya pada kelompok eksperimen diberikan perlakuan berupa model pembelajaran talking stick berbantuan rubrik surat kabar, sedangkan pada kelompok kontrol tidak diberikan perlakuan atau dengan kata lain dibelajarkan dengan pembelajaran konvensional. Setelah diberikan perlakuan, kelompok eksperimen dan kelompok kontrol diberikan post-test untuk memperoleh data keterampilan membaca.

Populasi dalam penelitian ini adalah seluruh siswa Kelas V SD Negeri Gugus IX Kintamani yang berjumlah 315 orang siswa. Berdasarkan karakteristik populasi dan tidak bisa dilakukannya pengacakan individu, maka dalam penelitian ini sampel dari populasi diambil dengan teknik random sampling. Teknik random sampling merupakan pengambilan anggota sampel dari populasi secara acak tanpa 
memperhatikan strata yang terdapat dalam populasi (Sugiyono, 2015). Pengambilan sampel dalam penelitian ini dilakukan dengan cara pengundian secara acak. Setelah dilakukan pengundian, diperoleh hasil kelas V SD Negeri 6 Songan dengan jumlah 37 orang siswa sebagai kelompok eksperimen dan kelas V SD Negeri 9 Songan dengan jumlah 38 orang siswa sebagai kelompok kontrol.

Data yang dikumpulkan dalam penelitian ini adalah data keterampilan berbicara pada siswa kelas $\mathrm{V}$ SD Gugus IX Kintamani tahun ajaran 2017/2018. Data tersebut dikumpulkan melalui metode tes. Adapun instrumen yang digunakan untuk memperoleh data keterampilan berbicara adalah rubrik penilaian keterampilan membaca.

Metode analisis data dalam penelitian ini adalah analisis statistik inferensial. Analisis statistik inferensial merupakan teknik analisis data yang digunakan untuk menentukan sejauh mana kesamaan antara hasil yang diperoleh dari suatu sampel dengan hasil yang didapatkan pada populasi keseluruhan. Pada penlitian ini, sebelum dilakukan uji hipotesis terlebih dahulu dilakukan uji prasyarat analisis yang meliputi uji normalitas sebaran data dan uji homogenitas varians. Uji normalitas sebaran data dalam penelitian ini menggunakan rumus Chi-kuadrat $(\chi 2)$ dengan kriteria pengujian pada taraf signifikansi 5\% dan $\mathrm{dk}=5$ adalah jika $\chi_{\_}$hitung^${ }^{\wedge} 2 \leq \chi_{-}$tabel$^{\wedge} 2$ maka distribusi data dinyatakan normal, sedangkan jika $\chi_{\_}$hitung ${ }^{\wedge} 2>\chi_{\_}$tabel $^{\wedge} 2$ maka distribusi data dinyatakan tidak normal. Uji homogenitas varians dilakukan dengan uji $\mathrm{F}$ dengan kriteria pengujian pada taraf signifikansi $5 \%$ dengan dk untuk pembilang $=\mathrm{n} 1-1$ dan dk untuk penyebut $=\mathrm{n} 2-1$, jika Fhitung $<$ Ftabel maka varians kedua kelompok data adalah homogen. Sebaliknya jika Fhitung > Ftabel maka kedua kelompok data dinyatakan tidak homogen (heterogen).

Jika data yang diperoleh telah memenuhi uji prasyarat analisis selanjutnya dilakukan uji hipotesis dengan analisis statistik parametrik. Analisis statistik yang digunakan untuk menguji hipotesis penelitian ini adalah uji-t dengan rumus polled varians. Dengan kriteria jika harga thitung $\leq$ ttabel, maka HO yang berbunyi tidak terdapat pengaruh model pembelajaran talking stick berbantuan rubrik surat kabar terhadap keterampilan berbicara siswa kelas V SD Negeri gugus IX Kintamani tahun ajaran 2017/2018. diterima dan Ha ditolak, dan jika harga thitung > ttabel maka H0 ditolak dan Ha diterima pada taraf signifikansi $5 \%$ dengan $\mathrm{dk}=\mathrm{n} 1+\mathrm{n} 2-2$.

\section{Hasil dan Pembahasan}

Berdasarkan hasil post-test data keterampilan berbicara pada 37 orang siswa di kelompok eksperimen menunjukkan bahwa nilai tertinggi yang diperoleh siswa adalah 88 dan nilai terendah yang diperoleh siswa adalah 60. Dari sebaran data tersebut diperoleh rata-rata (mean) sebesar 73,49 yang termasuk kriteria cukup (C) setelah dikonsultasikan dengan tabel konversi PAP skala lima. Varians data keterampilan berbicara pada siswa kelompok eksperimen adalah 38,70 dengan standar deviasi 6,22. Data keterampilan membaca pada siswa pada kelompok eksperimen disajikan dalam histogram berikut.

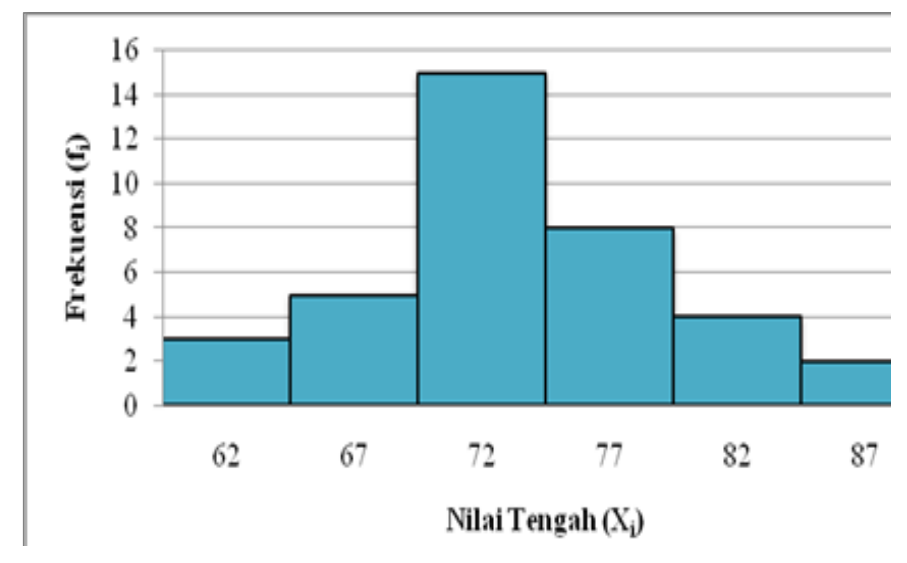

Gambar 2. Histogram Data Keterampilan Berbicara Siswa Kelompok Eksperimen

Berdasarkan histogram tersebut dapat dideskripsikan bahwa frekuensi pada kelas interval pertama dengan nilai tengah 62 sebanyak 3 orang, frekuensi pada kelas interval kedua dengan nilai tengah 67 sebanyak 5 orang, frekuensi pada kelas interval ketiga dengan nilai tengah 72 sebanyak 15 orang, frekuensi pada kelas interval keempat dengan nilai tengah 77 sebanyak 8 orang, frekuensi pada kelas interval kelima dengan nilai tengah 82 sebanyak 4 orang, dan frekuensi pada kelas interval keenam 
dengan nilai tengah 87 sebanyak 2 orang. Kelas interval dengan frekuensi tertinggi terletak pada nilai tengah 72 dan kelas interval dengan frekuensi terendah terletak pada nilai tengah 87.

Berdasarkan hasil post-test data keterampilan berbicara pada 38 orang siswa di kelompok kontrol menunjukkan bahwa nilai tertinggi yang diperoleh siswa adalah 84 dan nilai terendah yang diperoleh siswa adalah 56. Dari sebaran data tersebut diperoleh rata-rata (mean) sebesar 70,03 yang termasuk kriteria cukup (C) setelah dikonsultasikan dengan tabel konversi PAP skala lima. Varians data keterampilan membaca pada siswa kelompok kontrol adalah 35,86 dengan standar deviasi 5,99. Data keterampilan berbicara pada siswa pada kelompok eksperimen disajikan dalam histogram berikut.

Gambar 3. Histogram Data Keterampilan Berbicara Siswa Kelompok Kontrol

Berdasarkan histogram tersebut dapat dideskripsikan bahwa frekuensi pada kelas interval pertama dengan nilai tengah 57 sebanyak 1 orang, frekuensi pada kelas interval kedua dengan nilai tengah 62 sebanyak 6 orang, frekuensi pada kelas interval ketiga dengan nilai tengah 67 sebanyak 10 orang, frekuensi pada kelas interval keempat dengan nilai tengah 72 sebanyak 14 orang, frekuensi pada kelas interval kelima dengan nilai tengah 77 sebanyak 4 orang, dan frekuensi pada kelas interval ketujuh dengan nilai tengah 82 sebanyak 3 orang. Kelas interval dengan frekuensi tertinggi terletak pada nilai tengah 72 dan kelas interval dengan frekuensi terendah terletak pada nilai tengah 57.

Sebelum dilakukan pengujian hipotesis, dilakukan uji prasyarat yang meliputi uji normalitas sebaran data dan uji homogenitas varians. Uji normalitas dimaksudkan untuk mengetahui apakah sebaran data skor keterampilan berbicara pada siswa pada kelompok eksperimen dan kelompok kontrol berdistribusi normal atau tidak sehingga dapat menenetukan teknik analisis datanya.

Berdasarkan hasil uji normalitas kelompok eksperimen, diperoleh Chi Kuadrat hitung $\left(\chi^{2}{ }_{\text {hitung }}\right)=$ 10,502 kemudian nilai tersebut dibandingkan dengan Chi Kuadrat tabel pada taraf signifikansi 5\% dengan $\mathrm{dk}=5,\left(\chi^{2}\right.$ tabel $)=11,070$. Hal ini menunjukkan bahwa $\chi^{2}$ hitung $<\chi^{2}{ }_{\text {tabel }}$ berarti data keterampilan berbicara pada siswa kelompok eksperimen berdistribusi normal.

Berdasarkan hasil uji normalitas kelompok kontrol, diperoleh Chi Kuadrat hitung ( $\chi^{2}$ hitung) $=$ 8,351 kemudian nilai tersebut dibandingkan dengan Chi Kuadrat tabel pada taraf signifikansi $5 \%$ dengan $\mathrm{dk}=5,\left(\chi^{2}\right.$ tabel $)=11,070$. Hal ini menunjukkan bahwa $\chi^{2}$ hitung $<\chi^{2}$ tabel berarti data keterampilan berbicara pada siswa kelompok kontrol berdistribusi normal.

Pengujian homogenitas varians antar kelompok dimaksudkan untuk meyakinkan bahwa perbedaan yang diperoleh uji-t benar - benar berasal dari perbedaan antar kelompok bukan disebabkan oleh perbedaan di dalam kelompok. Dari hasil analisis diperoleh $\mathrm{F}_{\mathrm{hitung}}=1,08$. Hasil ini kemudian dibandingkan dengan $\mathrm{F}_{\text {tabel }}$ dengan dk pembilang $37-1=41$ dan dk penyebut $38-1=43$ dengan taraf signifikansi 5\%, sehingga diperoleh $\mathrm{F}_{\text {tabel }}=1,75$. Hal ini berarti $\mathrm{F}_{\text {hitung }}<\mathrm{F}_{\text {tabel }}$, sehingga data kelompok eksperimen dan kelompok kontrol memiliki varians yang homogen.

Berdasarkan hasil uji prasyarat yang terdiri dari uji normalitas sebaran data dan uji homogenitas varians, disimpulkan bahwa data kedua kelompok sampel berdistribusi normal dan memiliki varians yang homogen. Dengan demikian, uji hipotesis menggunakan uji-t dengan rumus polled varians dapat dilakukan. 
Tabel 1. Rekapitulasi Hasil Analisis Uji-t Kelompok Sampel Penelitian

\begin{tabular}{ccccccc}
\hline Kelompok Sampel & $\mathbf{N}$ & $\mathbf{d k}$ & $\bar{X}$ & $\mathbf{t}_{\text {hitung }}$ & $\mathbf{t}_{\text {tabel }}$ & Keterangan \\
\hline Eksperimen & 37 & 73 & 73,49 & 2,463 & 2,000 & \multirow{2}{*}{$\mathrm{H}_{0}$ ditolak } \\
Kontrol & 38 & 70,03 & & \\
\hline
\end{tabular}

Berdasarkan uji hipotesis diperoleh $\mathrm{t}_{\text {hitung }}=2,463$ sedangkan pada taraf signifikansi $5 \%$ dengan $\mathrm{dk}$ $=73$ diperoleh nilai $t_{\text {tabel }}=2,00$ sehingga $t_{\text {hitung }}=2,463>t_{\text {tabel }}=2,00$. Dengan demikian, hipotesis nol $\left(H_{0}\right)$ ditolak. Hal ini menunjukkan bahwa terdapat pengaruh model pembelajaran talking stick berbantuan rubrik surat kabar terhadap keterampilan berbicara siswa kelas V SD Negeri gugus IX Kintamani tahun ajaran 2017/2018. Berdasarkan hasil post-test yang telah diberikan kepada kedua kelompok sampel penelitian, diperoleh hasil perhitungan analisis data yang menunjukkan bahwa nilai rata-rata dari kelompok siswa yang mengikuti pembelajaran melalui model pembelajaran talking stick berbantuan rubrik surat kabar memperoleh nilai rata-rata sebesar $X=73,49$, sedangkan kelompok siswa yang mengikuti pembelajaran konvensional memperoleh nilai rata-rata sebesar $X=70,03$. Jadi nilai rata-rata dari kedua kelompok memiliki perbedaan sebesar 3,46.

Berdasarkan hasil temuan tersebut, dapat dinyatakan kedua kelompok sampel penelitian yang memiliki kemampuan setara, setelah diberikan perlakuan berupa pembelajaran dengan model pembelajaran talking stick berbantuan rubrik surat kabar dan mengikuti pembelajaran konvensional diperoleh hasil penguasaan keterampilan berbicara yang berbeda. Hal ini dapat dilihat dari rata - rata siswa yang mengikuti pembelajaran menggunakan model pembelajaran talking stick berbantuan rubrik surat kabar lebih tinggi dibandingkan dengan rata - rata siswa yang mengikuti pembelajaran konvensional. Perbedaan hasil penguasaan keterampilan berbicara dengan perolehan nilai rata-rata yang lebih tinggi pada kelompok eksperimen dibandingkan kelompok kontrol disebabkan oleh perlakuan berupa model pembelajaran talking stick berbantuan rubrik surat kabar yang diberikan pada kelompok eksperimen.

Model pembelajaran talking stick berbantuan rubrik surat kabar merupakan model pembelajaran yang digunakan untuk meningkatkan cara belajar siswa menuju belajar lebih baik, mendorong siswa untuk berani mengemukakan pendapat, meningkatkan partisipasi siswa, memberikan kesempatan pada siswa untuk berinteraksi dan belajar bersama-sama dengan bantuan media pembelajaran surat kabar yang juga dapat meningkatkan keterampilan dan kemampuan yang dimiliki siswa. Selain itu, model pembelajaran talking stick berbantuan rubrik surat kabar juga dapat melatih siswa dalam membaca dan memahami dengan lebih cepat materi yang dipelajari serta menguji kesiapan siswa dalam penguasaan pelajaran.

Hasil penelitian ini mendukung hasil penelitian sebelumnya yang disampaikan oleh Ni Kadek Sri Astuti (2017) yang menyatakan bahwa model pembelajaran talking stick berbasis concept song berpengaruh terhadap kompetensi pengetahuan IPA siswa. Penelitian lain yang memiliki kesamaan dengan penelitian ini adalah penelitian yang dilakukan oleh Ni Putu Fajar Wrespati Eka Putri (2016) yang menyatakan bahwa adanya peningkatan persentase rata-rata penguasaan kompetensi keterampilan berbicara siswa pada siklus I sebesar 74,19\% menjadi $82,78 \%$ pada siklus II. Peningkatan penguasaan kompetensi keterampilan berbicara dari siklus I ke siklus II mencapai 8,59\%.

Berdasarkan paparan tersebut, dapat dikatakan bahwa model pembelajaran talking stick berbantuan rubrik surat kabar berpengaruh terhadap keterampilan berbicara siswa kelas V SD Gugus IX Kintamani tahun ajaran 2017/2018.

\section{Simpulan dan Saran}

Berdasarkan Hasil analisis data keterampilan berbicara sampel diperoleh thitung $=2,463$ sedangkan nilai ttabel pada taraf signifikansi $5 \%$ dengan derajat kebebasan $(\mathrm{dk}=37+38-2=73)$ adalah 2,00. Karena thitung $>$ ttabel $(2,463>2,00)$ maka $\mathrm{H} 0$ yang berbunyi tidak terdapat pengaruh model pembelajaran talking stick berbantuan rubrik surat kabar terhadap keterampilan berbicara siswa kelas $\mathrm{V}$ SD Negeri gugus IX Kintamani tahun ajaran 2017/2018 ditolak dan Ha yang berbunyi terdapat pengaruh model pembelajaran talking stick berbantuan rubrik surat kabar terhadap keterampilan berbicara siswa kelas V SD Negeri gugus IX Kintamani tahun ajaran 2017/2018 diterima. Jadi, dapat disimpulkan bahwa terdapat pengaruh model pembelajaran talking stick berbantuan rubrik surat kabar terhadap keterampilan berbicara siswa kelas V SD Negeri gugus IX Kintamani tahun ajaran 2017/2018.

Berdasarkan temuan penelitian, kepada guru disarankan agar lebih kreatif dan inovatif untuk memfasilitasi siswa dalam pembelajaran berupa sumber belajar dan kesempatan yang lebih besar bagi 
siswa dalam pembelajaran dengan menggunakan model pembelajaran talking stick berbantuan rubrik surat kabar sehingga tercipta pembelajaran bermakna dan menyenangkan bagi siswa. Sekolah hendaknya dapat menggunakan hasil penelitian ini sebagai pendukung sumber belajar guru untuk menunjang pembelajaran agar siswa semakin termotivasi untuk belajar sehingga sekolah mampu meningkatkan mutu sekolah melalui peningkatan kualitas dan hasil belajar siswa. Peneliti lain disarankan agar memanfaatkan hasil penelitian ini sebagai kajian penelitian relevan sebagai penunjang penelitian selanjutnya dengan kajian yang lebih luas dan mendalam mengenai model pembelajaran talking stick berbantuan rubrik surat kabar dalam kaitannya dengan hasil belajar baik kompetensi pengetahuan, sikap, maupun keterampilan.

Terimakasih disampaikan kepada Bapak I Wayan Suandera, S.Pd.H., selaku Kepala SD Negeri 6 Songan dan Bapak I Ketut Cukup Indrawan, S.Pd.SD selaku Kepala SD Negeri 9 Songan yang telah memberikan ijin untuk melaksanakan penelitian di sekolah yang dipimpinnya. Terimakasih juga diucapkan kepada Ibu Ni Kadek Sariyanti, S.Pd.SD selaku wali kelas V A di SD Negeri 6 Songan dan Ibu Ni Kadek Novi Diantari, S.Pd.B selaku Wali Kelas V A di SD Negeri 9 Songan atas segala bantuan dan kerjasamanya selama penelitian sehingga penelitian dapat berlangsung sesuai harapan. Begitu pula kepada Ibu Dr. M. G. Rini Kristiantari, M.Pd, selaku dosen pembimbing I dan Bapak Drs. I Nengah Suadnyana, M.Pd selaku dosen pembimbing II yang telah memberikan bimbingan, arahan petunjuk dan motivasi selama penelitian ini. Serta semua pihak yang telah membantu dalam penyelesaian artikel ini.

\section{Daftar Rujukan}

Agung, A. A. Gede. 2014. Metodologi Penelitian Pendidikan. Malang: Aditya Media Publishing.

Anitah W., Sri. 2014. Strategi Pembelajaran di SD. Tangerang Selatan: Universitas Terbuka.

Arikunto, Suharsimi. 2015. Dasar-Dasar Evaluasi Pendidikan. Jakarta: Bumi Aksara.

Darmadi, Hamid. 2011. Metode Penelitian Pendidikan. Bandung: Alfabeta.

Daryanto. 2011. Media Pembelajaran. Bandung: PT Sarana Tutorial Nurani Sejahtera.

Hernawan, Asep Herry. 2014. Pengembangan Kurikulum dan Pembelajaran di SD. Tangerang Selatan: Universitas Terbuka.

Koyan, I Wayan. 2007. Statistika Terapan (Teknik Analisis Data Kuantitatif). Singaraja: UNDIKSHA.

Kurniasih, Imas dan Berlin Sani. 2017. Ragam Pengembangan Model Pembelajaran Untuk Peningkatan Profesionalitas Guru. Surabaya: Kata Pena

Mulyasa. 2010. Implementasi Kurikulum Tingkat Satuan Pendidikan. Jakarta: Bumi Aksara

Nurgiyantoro. 1995. Penilaian dalam Pengajaran Bahasa dan Sastra. Yogyakarta: BPFE-Yogyakarta

Nurkholis. 2013. Pendidikan Dalam Upaya Memajukan Teknologi . Jurnal Kependidikan, Vol. 1 No. 1 Nopember 2013

Safari. 1997. Pengujian dan Penilaian Bahasa dan Satra Indonesia. Jakarta: PT. Kartanegara

Setyosari. 2015. Metode Penelitian \& Pengembangan. Jakarta: Prenada Media Grup

Sugiyono. 2010. Statistika Untuk Penelitian. Bandung: Alfabeta

Sugiyono. 2015. Metode Penelitian Pendidikan. Bandung: Alfabeta

Sukardi. 2012. Metodologi Penelitian Pendidikan. Jakarta: PT Bumi Aksara

Tarigan, Henry Guntur. 2008. Berbicara Sebagai Suatu Keterampilan Berbahasa. Bandung: Percetakan Angkasa

Tarigan, Henry Guntur. 2008. Teknik Pengajaran Keterampilan Berbahasa. Bandung: Percetakan Angkasa 